\title{
Hemşirelerin Yetenek Yönetimi Algıları ile Algılanan Liderlik Tarzı ve Kişilik Özellikleri Arasındaki İlişkiler
}

The Relationships Between Nurses' Perceptions of Talent Management, Perceived Leadership Style and Personality Traits

\author{
Hanife TİRYAKİ ŞEN ${ }^{1}$, Fatma DEMİRKAYA², Handan ALAN ${ }^{3}$, Şehrinaz POLAT ${ }^{4}$
}

\section{ÖZ}

$\mathrm{Bu}$ çalışmanın amacı, hemşirelerin yetenek yönetimi algısının liderlik tarzı ve kendi kişilik özellikleri ile ilişkisinin belirlenmesidir. Tanımlayıcı nitelikte olan bu araştırmanın evrenini bir üniversite ve bir kamu hastanesinde çalışan toplam 800 hemşire oluşturdu. Çalışmada örnekleme yöntemine gidilmeyip çalışmaya katılmayı kabul eden 610 hemşireden veri alındı. Veriler, Kişisel Bilgi Formu, Yetenek Yönetimi Ölçeği, Beş Faktör Kişilik Özellikleri Ölçeği ve Çok Faktörlü Liderlik Tarzları Ölçekleri ile toplandı. Çalışmanın değerlendirilmesinde, tanımlayıcı analizler, değişkenler arası ilişkilerin belirlenmesi için Pearson Moment çift yönlü korelasyon ve regresyon analizi kullanıldı. Hemşirelerin yetenek yönetimi algısının orta düzeyde olduğu bulundu. Hemşirelerin yetenek yönetimi algısı ile liderlik tarzı alt boyutları ile anlamlı ilişkiler olduğu tespit edildi. Hemşirelerin yetenek yönetimi algısı ile kişilik özellikleri alt boyutları arasında ilişki olduğu bulundu. Algılanan liderlik özellikleri ve kişilik özellikleri alt boyutlarının hemşirelerin yetenek yönetimi algılarını açıklamada etkisi olduğu sonucuna ulaşıldı. Yönetici hemşirelerin dönüşümsel lider yönünü yüksek düzeyde algılayan hemşireler yeteneklerinin de yönetildiğini algilamaktadır.

Anahtar Kelimeler: Hemşire, Yetenek Yönetimi, Liderlik Tarzı, Kişilik Özellikleri

\begin{abstract}
The aim of this study is to determine the relationship between nurses' perception of talent management with their leadership style and their own personality traits. A total of 800 nurses working in a university and a public hospital comprised the universe of this descriptive study. Data were obtained from 610 nurses who did not use the sampling method and agreed to participate in the study. The data were collected by Personal Information Form, Talent Management Scale, Five Factor Personality Traits Scale and Multifactor Leadership Styles Scales. In the evaluation of the study, descriptive analysis, Pearson Moment bidirectional correlation and regression analysis were used to determine the relationships between variables. Significant relationships were found between nurses' talent management perception and leadership style sub-dimensions. It was found that there was a relationship between nurses' perception of talent management and personality traits subdimensions. It was concluded that perceived leadership traits and personality traits sub-dimensions had an effect on explaining nurses' perceptions of talent management. Nurses who perceive the transformational leadership aspect of manager nurses at a high level perceive that their skills are also managed.
\end{abstract}

Keywords: Nurse, Talent Management, Leadership Style, Personality Trait

Bir üniversitenin Girişimsel Olmayan Araştırmalar Etik Kurulundan onay alındı (Tarih: 28/05/2018; Sayl: E.14484).

${ }^{1}$ Dr., Hanife TİRYAKİ ȘEN, Hemşirelikte Yönetim,İstanbul Sağlık Müdüllüğü, Sağlık Hizmetleri Başkanlığı, hanifetiryaki@ gmail.com ORCID: 0000-0003-3350-1701

${ }^{2}$ Uz. Hemşire, Fatma DEMIRKAYA, Hemşire, İstanbul Sağlık Müdürlüğü Sağlık Hizmetleri Başkanlığı, fatmakaya2@gmail.com, ORCID: 0000-0001-8318-3030

${ }^{3}$ Dr. Öğr. Üyesi, Handan ALAN, Hemşirelikte Yönetim, İstanbul Üniversitesi-Cerrahpaşa, Florence Nightingale Hemşirelik Fakültesi, Hemșirelikte Yönetim AD, İstanbul, handanalan @yahoo.com, ORCID: 0000-0001-7414-2288

${ }^{4}$ Dr. Öğr. Üyesi, Şehrinaz POLAT, İstanbul Üniversitesi, Hemşirelik Fakültesi, İstanbul, sehrinaz.polat@gmail.com, ORCID ID: 0000-00021884-897X 


\section{GİRISS}

Günümüz dünyasında küreselleşmenin etkisi, teknolojinin gelişmesi, bilimsel bilginin artması, birlikte çalışan farklı kuşaklardaki personelin yönetimi, görevinde yetkin personel eksikliği ve benzeri nedenlerle örgütlerin yaşadıkları önemli zorluklardan biri yeteneklerin gelişimi ve yetenekli personelin elde tutulmasıdır. ${ }^{1}$ Çünkü dünyadaki insangücü daha eğitimli duruma gelmiş, çeşitlenmiş, hareketlenmiş ve iş yapma biçimlerinde değişiklikler olmuştur. $\mathrm{Bu}$ değişiklikler ve gelişmelere cevap verebilecek insangücünün desteklenmesi ve doğru yönlendirilmesi gerekliliği, yeteneğin nasıl yönetileceği konusuna verilen önemi artırmıştır. $^{2}$

İşlerinde başarılı ve yetenekli çalışanlar, gayretli, iradeli, kararlı, alanında uzmanlaşma çabasında, yeni deneyimlere açık, hayal gücü yüksek, ayırt edici, esnek, özdenetim sahibidir. Bu çalışanlar zamanı iyi yönetir, performans düzeyleri yüksektir ve görevlerinin gerektirdiği pratik bilgi ve deneyime sahiptirler. ${ }^{3}$ Çalışanların verdiği hizmetin istikrarla sürdürülmesi, yeni başarı seviyelerinin yakalanmas1, performans ve memnuniyetin önünde bulunan engelleri kaldıracaktır. ${ }^{2,4} \mathrm{Bu}$ yüzden bu özelliklere sahip yetenekli çalışanların tespit edilmesi için geçerli ve güvenilir stratejiler geliştirilmesi gerekmektedir. ${ }^{3} \quad$ Yetenek yönetimi, doğru becerilere sahip yetkin bireylerin doğru pozisyon almasını sağlar. ${ }^{5}$ Yetenek yönetimi; örgütün performansını arttıran, potansiyeli yüksek çalışanların geliştirilmesi, motive edilmesi, teşvik edilmesi ve elde tutulmasını içermektedir. ${ }^{6}$ Smith (2007) ile Ashton \& Morton (2005), Örgütlerde etkin yetenek yönetimi için, yüksek potansiyeli olan çalışanların belirlenmesi, geliştirilmesi, örgütte tutulması örgütlere rekabet avantajı sağlamada önemli bir faktör olduğunu bildirmişlerdir. ${ }^{7-8}$ Ayrıca kurumsal başarı için de itici bir güçtür. Nitekim yapılan bir çalışmada yetenek yönetimi ve örgütsel başarı puanları arasında pozitif yönde güçlü bir korelasyon olduğu tespit edilmiştir. ${ }^{1}$

Kaynağı yetenekli çalışanlar olan sektörlerden biri de sağlık sektörüdür. Sağlık sektöründe yüksek kaliteli, düşük maliyetli ve hasta güvenliği odaklı hizmete verilen önem giderek artmaktadır ve beraberinde rekabeti de getirmiştir. Nüfusun yaşlanması, sosyodemografik özelliklerin değişimi, kronik hastalıklarla mücadele ve yaşam tarzı değişikliklerine bağlı ortaya çıkan hastalıklarda görülen artış, sağlık insangücünde yetenek gelişimine dikkat çekilmesine sebep olmuştur.

Mckinsey Company ve Londra Ekonomi ve Siyaset Bilimi Okulu (2008) tarafindan yapılan çalışmada yetenek yönetiminin yatan hasta enfeksiyonları ve hasta geri kabul oranlarında düşme, verimli çalışanlar, hasta memnuniyeti ve kar oranının artması ile ilişkili olduğu tespit edilmiştir. ${ }^{9}$ Buna karşın sağlık hizmetleri gerek hekim gerekse hemşire açısından yetenek kıtlı̆̆ karşıyadır. Pek çok sağlık profesyoneli kariyerlerinin bir noktasında sağlık bakım alanının dişında başka alanları düşünmektedir. $\mathrm{Bu}$ kararlar sağlık bakım alanı için pahalı maliyetleri beraberinde getirecektir. ${ }^{10}$ Yetenekli hemşirelerin iyi değerlendirilmesi gerekmektedir. Çünkü hemşirelerin tüm toplumlarda sağlık sisteminin en iyi destekçisi olduğu ve nitelikli hemşire eksikliğinin hasta sağlığını olumsuz etkileyebileceği Dünya Sağlık Örgütü (DSÖ) tarafından da belirtilmiştir. ${ }^{11}$ $\mathrm{Bu}$ bağlamda hemşire insangücünde kalite, ustalık, deneyim ve kültürü geliştirmek ve genişletmek için sağlı sektöründe yetenek yönetim sistemi kullanılmalıdır. ${ }^{2,10,12}$ 
Yetenekli çalışanlar örgütleri için varlıktır, kurum başarısının temelindedir. Yeteneğin değerlendirilmesi konusu kilit noktadır. Sağlık hizmetlerinde yetenekli hemşireleri değerlendirmenin bir yolu, hemşirelerin yeterliliğini, bağlılığını ve katkısını değerlendirmektir. ${ }^{3}$ Yüksek potansiyele sahip hemşireler belirlenirken bazı kriterler göz önünde bulundurulabilir. Yapılan bir çalışmada hastane yöneticileri yüksek potansiyele sahip personeli belirlerken en çok yeni rollerdeki başarı oranları, iş performansı kayıtları, liderlik yeterlilikleri, işe yönelik deneyim, teorik bilgi birikimi ve yetenekleri, öğrenme kapasitesi ve kişilik özelliklerine göre belirlediklerini belirtmişlerdir. ${ }^{13}$ Yetenekli hemşireleri bulma, işe alma ve elde tutma, değişim ajanı olarak bu hemşirelerin yönlendirilmesi; performansı, bakımın kalitesini yükseltmede ve rekabette avantaj sağlamada önemli olduğu belirtilmektedir. ${ }^{3-4}$ Hemşirelerde yetenek yönetiminin tüm bu getirilerine rağmen hastanelerin bu tür planlamaları bir kenara bırakarak teknik ve idari işlevlerle meşgul oldukları, hemşirelerde yetenek yönetimine dair planlamalarda eksikliklerin olduğu belirtilmektedir. ${ }^{9}$

Finansal olarak hayatta kalmayı sağlayabilecek, maliyet etkin ve kaliteli bakım sunumu için yetenekli hemşirelerin desteklenmesinde hemşire liderlere önemli görevler düşmektedir. Yetenekli çalışanlar yeteneksiz liderler tarafından yönetiliyorsa, örgüte bağl1lıkta azalma, işten ve meslekten ayrılma gibi durumların yaşanması, iş sürekliliği, güvenli ve kalite odaklı hasta bakım sunumunda problemlerin olmasına yol açar. ${ }^{14-15}$ Yüksek potansiyele sahip hemşirelerin tespit edilmesi ve bunların kritik görevlerde yer almasının sağlanması, hemşirelerin gerekli beceri ve yetkinliklere sahip olması için eğitim ve gelişim fırsatları sunma, hemşire liderlerin işgücünü yönetmede önemli sorumluluklarındandır. ${ }^{2}$ Yapılan bir çalışmada lider-üye etkileşimi ile yetenek yönetiminin ilişkili olduğu, lider-üye etkileşimi arttıkça yetenek yönetiminin de arttığı tespit edilmiştir. ${ }^{16}$ Burada üzerinde durulmas1 gereken bir nokta liderlerin tarzıdır. Kişilerin durumlarla ilgili bilgiyi işleme ve anlamlandırmadaki farklılıklara bağlı olarak kullandıkları liderlik tarzlarının başında etkileşimci ya da dönüşümcü liderlik davranışları gelmektedir. ${ }^{17}$

Etkileşimci liderler takipçileriyle değişime dayalı bir sistemde çalışırlar. Bu liderler takipçilerinden beklentileri ile onların görev ve sorumluluklarını kesin olarak belirler ve takipçilerine bildirirler. Ayrıca kendilerine bağlılık ve yerine getirilecek görevler karşılığında verilecek ödüller net olarak bellidir. Geleneklere ve geçmişe bağlıdırlar. ${ }^{17-18}$ Dönüşümcü liderler ise vizyona ulaşmak için takipçilerine yetki vererek güçlendirirler. Geleceğe yönelik, yeniliğe, değişime ve reforma açıktırlar. Dönüşümcü liderlikte, takipçileri bir amaç etrafında toplama, onları değişimin ve yeniliğin gerekliliğine inandırma ve onlara ilham kaynağı olmak önemlidir. Böylece takipçilerin çalışma arzuları artar. ${ }^{19}$ Dönüşümsel liderlerin duygusal, sosyal açıdan yeterli ve hisseden kişilik özelliğine sahip olması beklenmektedir. ${ }^{20}$ Church \& Waclawski (1999) yenilikçi ve güdüleyici kişilik özelliğine sahip liderlerin, uygulayıcı liderlere göre fazla dönüşümsel olduğunu belirtmişlerdir. ${ }^{21}$ Dönüşümsel liderlik merkezinde değişim olmasından dolayı sağlık hizmetlerinde sergilenebilecek en iyi liderlik tarzı olarak görülmektedir. ${ }^{22}$ Hemşirelerin liderlerinin tarzını ve yetenek yönetimini algılama biçimleri ve aralarındaki ilişki bu çalışmada cevabı aranan sorulardan biridir. 
Farklı kişilik özelliklerine sahip bireyler belli durumlarda farklı özellikte davranışlar sergileyebilir ve olayları algılamaları da kişilik özelliklerinin bir yansıması olarak kabul edilebilir. Bireyin kişiliğinin temel yapısının değişik boyutları olduğu ileri sürülmektedir. $\mathrm{Bu}$ boyutlardan; dişa dönük olanlar; enerjik, girişken ve sosyaldir, rahat iletişime geçerler. Duygusal değişkenlik gösterenler/nörotikler; endişeye yatkın ve kendine güvensiz, uyumlu olanlar; beraber çalışmayı seven, yumuşak kalpli, arkadaş canlıs1, güven vericidirler, yönetici olduklarında astlarını iyi motive ederler. Özdisiplin açısından kuvvetli olanlar; başarma isteği güçlü, azimli, dikkatli ve temkinlidirler. Organizasyonda çeşitli görevlerde başarı yüzdeleri yüksektir. Gelişime açık olanlar; zeki, meraklı, kuvvetli hayal gücüne sahip, entellektüeldirler. İyi bir değişim ajanı olarak görev alabilirler. ${ }^{23-25}$

Hemşirelerin kişilik özellikleri ile yetenek yönetimi algıları arasında herhangi bir ilişki olup olmadı̆̆ 1 yine bu çalışmada cevabı aranan sorulardan biridir. $\mathrm{Bu}$ çalışmada literatürden farklı olarak yetenek yönetimi uygulayan kurum ve kuruluşlar açısından değerlendirme yapılmamış, yetenek yönetimi çalışan perspektifinden değerlendirilmeye çalışılmıştır. $\mathrm{Bu}$ çalışmada hemşirelerin kurumlarındaki yetenek yönetimini algılama düzeyinin; algılanan liderlik tarzı ve kendi kişilik özellikleri ile ilişkili olup olmadığının belirlenmesi amaçlanmıştır.

\section{MATERYAL VE METOT}

\section{Araștırma Soruları:}

1. Hemşirelerin yetenek yönetimi alg1 düzeyi nedir?

2. Yetenek yönetimi algısı ve algılanan liderlik tarzı arasında ilişki var mıdır?

3. Yetenek yönetimi algısı ve kişilik özellikleri arasında ilişki var mıdır?

\section{Araştırmanın Tasarımı:}

Çalışma tanımlayıcı, ilişki arayıcı ve kesitsel tasarımda yapıldı.

\section{Araștırmanın Evren ve Örneklemi:}

Araştırmanın evrenini metropolitan bir şehir olan İstanbul ilinde bulunan bir üniversite $(\mathrm{N}=500)$ ve bir kamu hastanesinde $(\mathrm{N}=300) \quad$ çalışmakta olan 800 hemşire oluşturdu. $\mathrm{Bu}$ şehirde çalışan hemşireler farklı eğitim, kurs, seminer ve deneyim firsatlarına sahip olabilmektedir ve yeteneklerini geliştirerek ortaya çıkarma firsatı bulabilmektedirler. Çalışmanın örneklemi, evreni bilinen örnekleme yöntemi ile hesaplanmıştır. Evreni bilinen örnekleme yöntemi ile örnekleme alınacak minimum hemşire sayısı $\alpha=0,05$ düzeyinde ve $\% 90$ istatistiksel güç düzeyinde formülle 260 hemşire olarak hesaplandı (minimum $n_{\text {hemşire }}=260$ ). Rastgele örnekleme yöntemi kullanıldı. Anketler 800 hemşireye açıklama yapılarak dağıtıldı. 610 hemşire anketleri tam ve kullanılabilir olarak araștırmacılara teslim etti. Anketlerin geri dönüş oranı $76.25 \%$ olarak hesaplandi.

\section{Veri Toplama Araçları}

$\mathrm{Bu}$ çalışmada Kişisel Bilgi Formu, Yetenek Yönetimi Ölçeği, Beş Faktör Kişilik Özellikleri Ölçeği ve Çok Faktörlü Liderlik Tarzları Ölçeği kullanıldı.

\section{Kişisel Bilgi Formu:}

Araştırmacılar tarafından ilgili literatür doğrultusunda hazırlanan form, hemşirelerin bireysel (yaş, cinsiyet, medeni durum, eğitim düzeyi) ve mesleki özelliklerini (çalışılan kurum, meslekte çalışma süresi, kurumdaki çalışma süresi, birimde çalışma süresi) 
içermektedir. Form, toplamda sekiz sorudan oluşmaktadır.

\section{Yetenek Yönetimi Algısı Ölçeği:}

Hemşirelerin yetenek yönetimini ölçmek amacıyla, Tutar, Altıöz ve Çöp (2011) tarafindan geliştirilen yetenek yönetimi ölçeği kullanılmış olup, ölçek 5'li likert şeklindedir. ${ }^{26}$ Yetenek yönetimi ölçeği 18 maddeden oluşmaktadır ve tek faktörlüdür. Ölçeğin Cronbach Alpha katsayısı 0,93 olarak saptanmıştır. Bu çalışmada Cronbach alfa 0.90 olarak bulundu.

\section{Çok Faktörlü Liderlik Tarzları Ölçeği:}

Ölçek Bass (1985) tarafindan geliştirilmiş, Avolio, Bass ve Jung (1999) tarafindan düzenlenmiş, Demir ve Okan (2008) tarafindan Türkçeye uyarlanmıştır. ${ }^{27-29}$ Ölçekte dönüşümsel liderlik boyutu, telkin edici liderlik-karizma ile bireysel düzeyde ilgi alt boyutları ve etkileşimsel liderlik boyutunda istisnalarla aktif yönetim ve istisnalarla pasif yönetim alt boyutlarından oluşan 22 madde yer almaktadır. Tüm maddelere verilen yanitlar $1=$ Kesinlikle katılmiyorum 2= Kat1lmiyorum 3= Kararsızım, 4= Katıliyorum, 5= Kesinlikle Katılıyorum şeklinde beş puanlık bir ölçekte ölçüldü. $\mathrm{Bu}$ çalışmada alt boyutlarda Cronbach Alpha katsayısının 0.88 ile 0.96 arasında değiştiği görüldü.

\section{Beş Faktör Kişilik Özellikleri Ölçeği:}

John, Donahue ve Kentle (1991) tarafından geliştirilmiş ve ölçeğin Türkçe'ye uyarlanması Sümer, Lajunen ve Özkan (2005) tarafindan yapılmıştır. ${ }^{30,31} \mathrm{Bu}$ ölçek kişilik özelliklerinden "nörotiklik", "dışadönüklük", "gelişime açıklık", "uyumluluk" ve "özdisiplin" boyutlarını ölçmektedir. Ölçekte "nörotiklik" ve “dışadönüklük” faktörleri 8 'er madde, "uyumluluk" ve "özdisiplin" faktörleri 9'ar madde, "gelişime açılklk" faktörü ise 10 madde ile ölçülmektedir. 2., 6., 8., 9., 12., 18., 21., 23., 24., 27., 31., 34., 37., 41. ve 43.maddeler ters puanlandi. Tüm maddelere verilen yanıtlar $1=$ Hiç katılmıyorum 5= Tamamen katılıyorum şeklinde beş puanlık bir ölçekle ölçüldü. $\mathrm{Bu}$ çalışmada ölçeğin Cronbach alfa katsayısı 0.66 ile 0.82 arasında olduğu bulundu.

\section{Verilerin Analizi:}

Veriler IBM SPSS Statistics 21 paket programı ile analiz edildi. Verilerin analizinde tanımlayıcı analizler (sayı, yüzde, ortalama, standart sapma), ölçekler arası ilişkiyi saptamak için Pearson Moment çift yönlü korelasyon analizi ve regresyon analizi kullanıldı. Sonuçlar, $\mathrm{p}<0.05$ anlamlılık düzeyinde değerlendirildi.

\section{Araştırmanın Etik Boyutu:}

Çalışmanın yapılması için bir üniversitenin Girişimsel Olmayan Araştırmalar Etik Kurulundan onay alınd1 (tarih: 28/05/2018; no: E.14484). Kat1lımin gönüllü olduğu bildirilerek her katılımcıya araştırmayla ilgili bilgi formu dağıtıldı. Ölçekler isimsiz olarak dağıtıldı ve toplandı. Katılımcılara iade edilmedi. Basılı ölçekler sorumlu araştırmacı tarafindan saklandı. Dijital ortama aktarılan veriler ise sorumlu araştırmacı kişisel bilgisayarında saklandı. Araştırmanın başından sonuna kadar geçen süreçte gizlilik prensiplerine riayet edildi.

\section{Arastırmanın Kısıtlılıkları}

Alan yazında bu konuyla ilgili çok fazla çalışma olmaması tartışmada kısıtlılığa neden olduğu düşünülmektedir.

\section{BULGULAR VE TARTIŞMA}

\section{Kişisel Bilgilerin Dağılımı}

$\mathrm{Bu}$ çalışmada katılımcıların \%36,1'inin 26-35 yaş aralığında ve büyük çoğunluğunun kadın olduğu, medeni durum yüzdelerinin 
yaklaşık olarak eşit dağıldığı, eğitim düzeylerine bakıldığında \% 69,2'sinin lisans düzeyinde, \%61,3'ünün meslekte çalışma süresinin 10 yıl ve altında olduğu, \%72'sinin kurumda çalışma süresinin 10 yıl ve altında olduğu, \%64,6'sının birimde çalışma süresinin 10 yıl ve altında olduğu bulundu (Tablo 1).

Tablo 1. Hemşirelerin Sosyodemografik Özelliklerinin Dağılımı (N: 610)

\begin{tabular}{|c|c|c|c|c|c|}
\hline \multicolumn{2}{|c|}{ Değişkenler } & \multicolumn{2}{|c|}{$\begin{array}{l}\text { Toplam } \\
\text { (N:610) }\end{array}$} & \multirow{2}{*}{$\begin{array}{c}\text { Üniversite } \\
\text { Hastanesi } \\
(\mathrm{N}: 345) \\
\mathrm{N}\end{array}$} & \multirow{2}{*}{$\begin{array}{c}\text { Kamu } \\
\text { Hastanesi } \\
(\mathbf{N}: 265)\end{array}$} \\
\hline & & n & $\%$ & & \\
\hline Yaş & $\begin{array}{l}\leq 25 \text { yaş ve } \\
\text { alt1 }\end{array}$ & 173 & 28,4 & 41 & 132 \\
\hline \multirow{2}{*}{ Ort:32.69 \pm 9.14} & & & & & \\
\hline & 26-35 yas & 220 & 36,1 & 126 & 94 \\
\hline $\begin{array}{l}\min -\max : 19- \\
64\end{array}$ & $\begin{array}{l}\geq 36 \text { yaş ve } \\
\text { üzeri }\end{array}$ & 217 & 35,6 & 178 & 39 \\
\hline \multirow{2}{*}{ Cinsiyet } & Kadın & 524 & 85,9 & 311 & 213 \\
\hline & Erkek & 86 & 14,1 & 34 & 52 \\
\hline \multirow{2}{*}{$\begin{array}{l}\text { Medeni } \\
\text { Durum }\end{array}$} & Evli & 309 & 50,7 & 210 & 99 \\
\hline & Bekar & 301 & 49,3 & 135 & 166 \\
\hline \multirow{3}{*}{ Eğitim Düzeyi } & Lise+önlisans & 116 & 19,0 & 52 & 64 \\
\hline & Lisans & 422 & 69,2 & 239 & 183 \\
\hline & Lisansüstü & 72 & 11,8 & 54 & 18 \\
\hline $\begin{array}{l}\text { Mesleki } \\
\text { Deneyim }\end{array}$ & $\begin{array}{l}\leq 10 \text { yıl ve } \\
\text { üzeri }\end{array}$ & 374 & 61,3 & 161 & 213 \\
\hline \multirow[t]{2}{*}{ Ort: $10.53 \pm 9.57$} & $\begin{array}{l}11-20 \text { y1l } \\
\text { aras1 }\end{array}$ & 127 & 20,8 & 86 & 41 \\
\hline & $\begin{array}{l}\geq 21 \text { y1l ve } \\
\text { alt1 }\end{array}$ & 109 & 17,9 & 98 & 11 \\
\hline $\begin{array}{l}\text { Kurumsal } \\
\text { Deneyim }\end{array}$ & $\begin{array}{l}\leq 10 \text { yil ve } \\
\text { üzeri }\end{array}$ & 439 & 72,0 & 191 & 248 \\
\hline $\begin{array}{l}\text { Ort:8.33 } \pm 8.99 \\
\min -\max : 1-39\end{array}$ & $\begin{array}{l}\geq 11 \text { y1l ve } \\
\text { alt1 }\end{array}$ & 171 & 28,0 & 154 & 17 \\
\hline $\begin{array}{l}\text { Birim } \\
\text { Deneyimi }\end{array}$ & $\begin{array}{l}\leq 5 \text { yil ve } \\
\text { üzeri }\end{array}$ & 394 & 64,6 & 150 & 244 \\
\hline \multirow[t]{2}{*}{ Ort: $6.49 \pm 7.88$} & & & & & \\
\hline & $\geq 6$ yıl ve altı & 216 & 35,4 & 195 & 21 \\
\hline
\end{tabular}

Hemşirelerin yetenek yönetimi algıları, algılanan liderlik tarzı ve kişilik özellikleri ölçek puan ortalamaları

Her üç ölçek ortalamalarının 1'e yaklaşması düşük, 5'e yaklaşması ise yüksek düzey olarak değerlendirilmektedir. Hemşirelerin ölçek maddelerine verdikleri yanıtların ortalaması hemşirelerin yetenek yönetimi algılarının orta düzeyde olduğunu gösterdi (3,58 $\pm 0,55)$. Araştırmaya katılan hemşirelerin kişiliklerinin en fazla geçimlilik özelliği gösterdiği bulundu $(3,87 \pm 0,58)$. Ek olarak hemşirelerin yöneticilerinde algıladıkları liderlik tarzı puan ortalaması bireysel düzeyde ilgi boyutunda yüksek bulundu $(3,54 \pm 1,01)$ (Tablo 2).

Tablo 2. Hemşirelerin Yetenek Yönetimi Algıları, Kişilik Özellikleri Ve Liderlik Tarzı Algılamaları Ölçek Puan Ortalamaları

\begin{tabular}{lcccc}
\hline Ölçek & Alt boyut & $\begin{array}{c}\text { Madde } \\
\text { Sayısı }\end{array}$ & X & SD \\
& \multicolumn{1}{c}{18} & 3,58 & 0,55 \\
\hline Yetenek & - & & & \\
Yönetimi & & & &
\end{tabular}

Algisı

\begin{tabular}{|c|c|c|c|c|}
\hline \multirow{7}{*}{$\begin{array}{l}\text { Beş Faktör } \\
\text { Kişilik } \\
\text { Özellikleri } \\
\text { Ölçeği }\end{array}$} & Dişa & 8 & 3,43 & 0,66 \\
\hline & Dönüklük & & & \\
\hline & Sorumluluk & 9 & 3,81 & 0,59 \\
\hline & Açıklık & 10 & 3,33 & 0,59 \\
\hline & Geçimlilik & 9 & 3,87 & 0,58 \\
\hline & Duygusal & 8 & 2,73 & 0,54 \\
\hline & Dengesiz & & & \\
\hline \multirow{8}{*}{$\begin{array}{l}\text { Algılanan } \\
\text { Liderlik } \\
\text { Tarzı } \\
\text { Ölçeği }\end{array}$} & Telkin Edici- & 7 & 3,42 & 0,97 \\
\hline & Karizma & & & \\
\hline & Bireysel & 5 & 3,54 & 1,01 \\
\hline & Düzeyde İlgi & & & \\
\hline & İstisnalarla & 4 & 2,54 & 0,95 \\
\hline & Pasif Yönetim & & & \\
\hline & İstisnalarla & 6 & 3,52 & 0,87 \\
\hline & Aktif Yönetim & & & \\
\hline
\end{tabular}


Hemşirelerin kişilik özellikleri ve liderlik özellikleri ile yetenek yönetimi algılarının ilişkilendirilmesi

Yapılan Pearson Korelasyon analizi sonucunda; hemşirelerin yetenek yönetimi algıları ile kişilik özelliklerinden dışa dönüklük boyutu arasında $\mathrm{r}=0,19$ düzeyinde, pozitif yönde, çok zayıf güçte ve istatistiksel olarak çok ileri derecede ilişki olduğu bulundu. Yetenek yönetimi algısı, sorumluluk ( $\mathrm{r}=0,22)$, açıklık $(\mathrm{r}=0,20)$ ve geçimlilik $(\mathrm{r}=0,28)$ boyutları arasında pozitif yönde, zayıf güçte ve istatistiksel olarak çok ileri derecede, yetenek yönetimi algıları ile duygusal dengesizlik boyutu arasinda $\mathrm{r}=-0,19$ negatif yönde, çok zayıf güçte ve istatistiksel olarak çok ileri derecede anlamlı ilişki olduğu tespit edildi (Tablo 3).

Hemşirelerin yetenek yönetimi algıları ile liderlik tarzı algılarının istisnalarla pasif yönetim alt boyutu arasında $\mathrm{r}=-0,14$ düzeyinde, negatif yönde, çok zayıf güçte ve istatistiksel olarak çok ileri derecede, yetenek yönetimi algisı ile istisnalarla aktif yönetim alt boyutu arasında $\mathrm{r}=0,39$ düzeyinde pozitif yönde, zayıf güçte ve istatistiksel olarak çok ileri derecede, yetenek yönetimi algısı ile bireysel düzeyde ilgi $(\mathrm{r}=0,42)$ ve telkin edici-karizma $(\mathrm{r}=0,44)$ alt boyutları arasında pozitif yönde, orta güçte ve istatistiksel olarak çok ileri derecede anlamlı ilişki olduğu tespit edildi (Tablo 3).

Tablo 3. Hemşirelerin Yetenek Yönetimi Algılarının Kişilik Özellikleri ve Algılanan Liderlik Tarzı ile İlişkilendirilmesi

\begin{tabular}{|c|c|c|c|}
\hline Ölçek Adı & Alt Boyutları & & $\begin{array}{l}\text { nek Yönetimi } \\
\text { Algısı }\end{array}$ \\
\hline \multirow{5}{*}{$\begin{array}{l}\text { Beş } \\
\text { Faktörlü } \\
\text { Kişilik } \\
\text { Özellikleri } \\
\text { Ölçeği }\end{array}$} & Dişa Dönüklük & $\mathrm{r}$ & $0,19 * *$ \\
\hline & Sorumluluk & $\mathrm{r}$ & $0,22 * *$ \\
\hline & Açıklık & $\mathrm{r}$ & $0,20 * *$ \\
\hline & Geçimlilik & $\mathrm{r}$ & $0,28 * *$ \\
\hline & $\begin{array}{l}\text { Duygusal } \\
\text { Dengesiz }\end{array}$ & $\mathrm{r}$ & $-0,19 * *$ \\
\hline \multirow{6}{*}{$\begin{array}{l}\text { Çok } \\
\text { Faktörlü } \\
\text { Liderlik } \\
\text { Ölçeği }\end{array}$} & Telkin & $\mathrm{r}$ & $0,44^{* *}$ \\
\hline & Edici_Karizma & & \\
\hline & Bireysel & $\mathrm{r}$ & $0,42^{* *}$ \\
\hline & Düzeyde İlgi & & \\
\hline & $\begin{array}{l}\text { İstisnalarla Pasif } \\
\text { Yönetim }\end{array}$ & $\mathrm{r}$ & $-0,14^{* *}$ \\
\hline & $\begin{array}{l}\text { İstisnalarla Aktif } \\
\text { Yönetim }\end{array}$ & $\mathrm{r}$ & $0,39^{\text {** }}$ \\
\hline
\end{tabular}

Hemşirelerin yetenek yönetimi algısı ile kişilik özellikleri arasındaki ilişki basit doğrusal regresyon analizi ile saptand. Hemşirelerin yetenek yönetimi algılarındaki toplam değişimin; \% 4'ünü $\quad\left(\mathrm{R}^{2}=0,04\right)$ dışadönük, açık ve duygusal dengesiz kişilik özelliği, \% 5' ini $\left(\mathrm{R}^{2}=0,05\right)$ sorumlu kişilik özelliği, \% 8' ini $\left(\mathrm{R}^{2}=0,08\right)$ geçimli kişilik özelliği açıklıyordu (Tablo 4).

Tablo 4. Hemşirelerin Kişilik Özelliklerinin Yetenek Yönetimi Algılarına Etkisi

\begin{tabular}{|c|c|c|c|c|c|}
\hline $\begin{array}{l}\text { Bağımlı } \\
\text { değişken }\end{array}$ & $\begin{array}{l}\text { Bağımsız } \\
\text { değişken }\end{array}$ & $\mathbf{t}$ & $\mathbf{R}$ & $\mathbf{R}^{2}$ & Anlamlılık \\
\hline \multirow{10}{*}{$\begin{array}{l}\text { Yetenek } \\
\text { Yönetimi } \\
\text { Algısı }\end{array}$} & Sabit & 25,58 & \multirow{2}{*}{0,19} & \multirow{2}{*}{0,04} & $\mathrm{~F}=25,58$ \\
\hline & D1şadönüklük & 0,16 & & & $\mathrm{p}=0,00$ \\
\hline & Sabit & 19,30 & \multirow{2}{*}{0,22} & \multirow{2}{*}{0,05} & $\mathrm{~F}=33,04$ \\
\hline & Sorumluluk & 5,74 & & & $\mathrm{p}=0,00$ \\
\hline & Sabit & 23,32 & \multirow{2}{*}{0,20} & \multirow{2}{*}{0,04} & $\mathrm{~F}=25,49$ \\
\hline & Açıklık & 5,04 & & & $\mathrm{p}=0,00$ \\
\hline & Sabit & 17,47 & \multirow{2}{*}{0,28} & \multirow{2}{*}{0,08} & $\mathrm{~F}=52,24$ \\
\hline & Geçimlilik & 7,22 & & & $\mathrm{p}=0,00$ \\
\hline & Sabit & 36,40 & \multirow[b]{2}{*}{0,19} & \multirow[b]{2}{*}{0,04} & $F=23,69$ \\
\hline & $\begin{array}{l}\text { Duygusal } \\
\text { Dengesiz }\end{array}$ & $-4,86$ & & & $\mathrm{p}=0,00$ \\
\hline
\end{tabular}

Hemşirelerin yetenek yönetimi algısı ile algılanan liderlik tarzları arasındaki ilişki basit doğrusal regresyon analizi ile saptand. Hemşirelerin yetenek yönetimi algılarındaki toplam değișimin; \% 2'sini $\left(\mathrm{R}^{2}=0,02\right)$ liderlik algısının telkin edici-karizma, bireysel düzeyde ilgi ve istisnalarla pasif yönetim boyutu, \% 1 'ini $\left(\mathrm{R}^{2}=0,01\right)$, liderlik algisının istisnalarla aktif yönetim boyutu açıklıyordu (Tablo 5). 
Tablo 5. Hemşirelerin Algılanan Liderlik Tarzlarının Yetenek Yönetimi Algılarına Etkisi

\begin{tabular}{|c|c|c|c|c|c|}
\hline $\begin{array}{l}\text { Bağımlı } \\
\text { değişken }\end{array}$ & $\begin{array}{l}\text { Bağımsız } \\
\text { değişken }\end{array}$ & $\mathbf{t}$ & $\mathbf{R}$ & $\mathbf{R}^{2}$ & Anlamlılık \\
\hline \multirow{8}{*}{$\begin{array}{l}\text { Yetenek } \\
\text { Yönetimi } \\
\text { Algısı }\end{array}$} & Sabit & 36,67 & \multirow[b]{2}{*}{0,44} & \multirow[b]{2}{*}{0,02} & \multirow[b]{2}{*}{$\begin{array}{c}\mathrm{F}=150,24 \\
\mathrm{p}=0,00\end{array}$} \\
\hline & $\begin{array}{l}\text { Telkin } \\
\text { Edici- } \\
\text { Karizma }\end{array}$ & 12,25 & & & \\
\hline & Sabit & 37,03 & \multirow[b]{2}{*}{0,42} & \multirow[b]{2}{*}{0,02} & \multirow[b]{2}{*}{$\begin{array}{c}\mathrm{F}=136,48 \\
\mathrm{p}=0,00\end{array}$} \\
\hline & $\begin{array}{l}\text { Bireysel } \\
\text { Düzeyde } \\
\text { İlgi }\end{array}$ & 11,68 & & & \\
\hline & Sabit & 59,62 & \multirow[b]{2}{*}{0,15} & \multirow[b]{2}{*}{0,02} & \multirow[b]{2}{*}{$\begin{array}{c}\mathrm{F}=13,81 \\
\mathrm{p}=0,00\end{array}$} \\
\hline & $\begin{array}{l}\text { İstisnalarla } \\
\text { Pasif } \\
\text { Yönetim }\end{array}$ & $-3,71$ & & & \\
\hline & Sabit & 31,11 & \multirow[b]{2}{*}{0,39} & \multirow[b]{2}{*}{001} & \multirow[b]{2}{*}{$\begin{array}{c}\mathrm{F}=113,01 \\
\mathrm{p}=0,00\end{array}$} \\
\hline & $\begin{array}{l}\text { İstisnalarla } \\
\text { Aktif } \\
\text { Yönetim }\end{array}$ & 10,63 & & & \\
\hline
\end{tabular}

Yetenek yönetimi dünyada pek çok sektörün çözüm aradığ1 global bir problemdir. ${ }^{32}$ Hemşireliğin ise temel yeteneği bakımdır. Profesyonel hemşirelik bakımının mükemmel seviyeye ulaştırılması, bakım hizmetlerinin kalitesinin artması, hemşirelik hizmetlerinin sürekli iyileştirilmesi, optimal bireysel ve organizasyonel çıtılara ulaşılması için günümüzde yetenekli hemşirelere ihtiyaç duyulmaktadır. Çünkü hemşirelik hizmetlerinde hedefin sürekli olarak yükseltilmesine dair kabul edilmiş bir algı vardır. ${ }^{33}$ Abbasi ve arkadaşlarının (2010) çalışmalarında katılımcılar yetenek yönetimini, performans iyileştirme, yönetimde çeşitlilik oluşturma, gelecek için liderler geliştirme, mevcut yeteneklerin etkili ve verimli yönetimi ve çalışanları elde tutma düzeyini artırmaya yönelik olarak algıladıklarını belirtmişlerdir ve büyük bir çoğunluğu da liderlerin yetenek yönetimi konusunda yetkin olduklarını düşündüklerini belirtmişlerdir. $^{6}$

$\mathrm{Bu}$ araştırmada hemşirelerin yetenek yönetimi algısının orta düzeyde olduğu bulundu. $\mathrm{Bu}$ bulgunun nedeninin; katılımcıların tamamının kamu hastaneleri çalışanları olmasından dolayı, yetenek yönetimi yaklaşımını daha çok özel kurumlarda yapiliyor olarak algılamaları olabileceği düşünülmektedir. Kamuda işe alım süreçlerinin mevzuat çerçevesinde yapılması çalışanlarda bu tür bir algının oluşmasında rol oynamış olabilir. Ayrıca kamuda genellikle merkezileştirilen ve yönetim tarafindan organize edilen hemşirelik uygulamaları ve yönergelerde homojen özellikler taşıması hemşirelerde bu tür bir algılama oluşmasına katkıda bulunmuş olabilir. Hemşirelerin kendi imajlarına dayanarak ya da kurumlarında yaşadıkları olumlu veya olumsuz birtakım olaylara istinaden verdikleri cevaplar yetenek yönetimi algısının oluşmasında rol oynayabilir. Yapılan bir çalışmada toplam 72 hemşireden 43'ünün $\quad(\% 59,7) \quad$ yüksek düzeyde yetenekli olduğu bulunmuştur. Ayrıca, aynı çalışmanın bulguları düşük yetenekli ve çok yetenekli hemşireler arasında özellikleri açısından anlamlı bir farklılık olmadığını, bununla birlikte, hemşirelik bakımının kalitesinin, çok yetenekli hemşire grubunda daha iyi olduğu bildirilmiştir. ${ }^{34}$

Hemşirelikte yeteneği değerlendirmenin bir yolu, hemşirelerin yeterliliğini, bağlılığını ve katkısını değerlendirmektir.

Yetenek yönetimi algısı ile kişilik ve liderlik özellikleri alt boyutları arasındaki ilişkiler incelendiğinde genel bağlamda istatistiksel olarak çok ileri düzeyde, çok zayıf, zayıf ve orta düzeyde ilişkiler olduğu sonucunda ulaşıldı. Regresyon analizi bulgularında ise kişilik ve liderlik özellikleri algısı alt boyutlarının hemşirelerin yetenek yönetimi algılarını çok düşük oranlarla etkilediği sonucuna ulaşıldı.

Hemşirelerin, duygusal dengesiz kişilik özelliği arttıkça yetenek yönetimi algısı azalmaktadır. Duygusal dengesiz kişilik tipinde olan insanlar daha çok kaygı içerisinde, içine kapanık, güvensiz, incinebilir, strese karşı aşırı duyarlı olma gibi 
olumsuz nitelik taşıdığından bu tür insanların iş ortamında yeteneğin yönetildiğine ilişkin algılarının azalıyor olması beklenen bir bulgudur. ${ }^{35}$ Çünkü bu kişilik tipinde olan çalışanların etrafında olanları değerlendirme olanağı da oldukça az olacaktır.

Hemşirelerin yetenek yönetimi algıları ile liderlik tarzı algılarının alt boyutları arasında çok zayıf, zayıf ya da orta güçte ama çok ileri derecede anlamlı ilişki bulunmuştur. Çalışanların liderlerinin tarzını istisnalarla pasif yönetim boyutunda algılama durumları arttıkça yetenek yönetimi algısının azaldığı sonucuna ulaşıldı. Liderlerini istisnalarla pasif yönetim tarzıyla algılayan çalışanların yetenek yönetimi algılarının azalması beklenen bir durumdur. Linn ve arkadaşları (2007) yetenek yönetiminin uygulamada görünürlüğünden çok çalışanlar arasında nasıl algılandığının daha önemli olduğuna dikkat çekmektedirler. Yetenek yönetimine dair çalışanlarda algılama oluşturabilmek için liderlerin bazı eylemlerde bulunmaları gerekmektedir. Liderlerin sergilediği davranışlar organizasyon çıktılarının etkinlik ve etkililiğinde değişimler oluşturacaktır. ${ }^{36}$ $\mathrm{Bu}$ yönüyle Linn ve arkadaşlarının (2007) çalışması bu bulgu ile benzerlik göstermektedir.

Yetenek yönetimi algısı ile liderlik özellikleri algısı arasındaki ilişkiler incelendiğinde yöneticilerini dönüşümsel lider yönüyle algılayan hemşirelerin yeteneklerinin de yönetildiğini algıladıkları sonucuna ulaşıldı. Hemşireler liderlerini daha çok dönüşümcü olarak algıladıklarını belirttiler. Dönüşümcü liderler karizmatik ve etkilidir. Bu sayede kuruluşun misyon ve genel amaçları ile çalışanların bireysel hedeflerinin uyum sağlamasında bir köprü vazifesi görürler. $\mathrm{Bu}$ tip liderler aynı zamanda koçluk yaparak ve danışmanlık sağlayarak çalışanların bireysel gelişimi için destekleyici bir ortam oluştururlar.

Hemşireler yöneticilerinin kendilerini bu şekilde geliştirmeleri, mevcut potansiyellerini maksimuma çıkarmalarıyla ilgilendiğini algiladıklarında potansiyellerinin ve yeteneklerinin çalıştıkları kurum için önemli olduğu ve değerlendirildiği kanısına varırlar. $\mathrm{Bu}$ da onları görevleriyle daha fazla meşgul olmaya ve sağlık bakım hizmeti çıktılarını iyileştirmeye yöneltir. ${ }^{37-38}$

\section{SONUÇ VE ÖNERILLER}

Çalışmanın bulguları hemşirelerin yetenek yönetimi algılarının orta düzeyde olduğunu gösterdi. Algılanan liderlik özellikleri ve kişilik özellikleri alt boyutlarının hemşirelerin yetenek yönetimi algılarını açıklamada küçük etkileri olduğu sonucuna ulaşıldı. Hemşire yöneticilerini dönüşümsel lider yönüyle algılayan hemşireler yeteneklerinin de yönetildiğini daha yüksek seviyede algıliyordu. Hemşirelerin duygusal dengesiz kişilik özellikleri arttıkça yetenek yönetimi algıları azalıyordu. Gelecekte sağlık kurumlarında yetenek yönetimini daha kapsamlı çerçevede ele almaya yönelik çalışmalar yapılabilir. Yetenekli hemşirelerin tanımlanmasına ilişkin kriterlerin belirlenmesi, hemşirelerin yetenek yönetimi algılarını etkileyecek farklı etkenlerin incelenmesi, hemşirelerin yetenek yönetimi sistemini kurmaya yönelik metodolojik pilot çalışmalar yapılabilir. Ayrıca çalışma farklı statüdeki sağlık kurumlarında kamu-özel sektör karşılaştırması şeklinde yapılabilir.

$\mathrm{Bu}$ çalışma sağlık hizmetlerinde yetenek yönetiminin ihmal edilmiş durumuna çalışan perspektifinden bakarak yeni bir bakış açısı oluşturmuştur. Yönetici hemşirelerin hemşire insan kaynağı yönetiminin sistematize edilmesinde ve yetenek yönetimi uygulamalarının tasarımında hemşirelerin 
yetenek yönetimine ilişkin algıları ve bu algıyla etkileşimde olabilecek kişilik özelliklerini de göz önünde bulundurmaları yeteneğin verimli kullanılmasına katkı sağlayacaktır.

Hemşire yöneticiler organizasyonlarının günümüz sağlik hizmetleri ortamında rekabetçi kalabilmesi için yetenek yönetimi uygulamalarını stratejik planlamalarına dahil etmelidirler. Ayrıca hemşirelerin yeteneklerinin değerlendirildiğine ilişkin algıları hakkında farkındalık yaratarak içgörü kazanmaları yoluyla kurum hizmet çıktılarına olumlu katkı yapabilmelerini sağlayabilirler. Böylece verilecek bakımın kalitesinin artırılması ve mükemmelleştirilmesi sağlanacaktır. $\mathrm{Bu}$ çalışma belli sınırlılıklar altında yürütüldü. Veriler yalnızca kamu hastanelerinden toplandığı için katılımcıların algıları kurumlarının türüne göre etkilenmiş olabilir. Gelişigüzel örnekleme tekniği kullanıldı ve çalışma doğası gereği kesitseldi. $\mathrm{Bu}$ nedenlerden dolayı sonuçlar genelleştirilemez. Aynı kişi hem bağımlı hem de bağımsız değişken için veri sağladığı için bu durum bağımlı-bağımsız arasındaki ilişkilerin belirlenmesinde etki yaratmış olabilir. 


\section{KAYNAKLAR}

1. Taie, E.S.M.S. (2015). "Talent Management is The Future Challenge for Healthcare Managers for Organizational Success". American Research Journal of Nursing, 1 (1),18-27.

2. Douglas, K. (2015). "Talent Management, The Next Frontier: Retaining, Nurturing, and Growing Our Workforce. Nurse Leader, 11 (2), 23-25.

3. Alnuqaidan, H.A. ve Ahmad, M. (2019). "Comparison Between Highly-Talented and Low-Talented Nurses on Their Characteristics and Quality of Nursing Care". Diversity \& Equality in Health and Care, 16 (2), 30-35.

4. Dahshan, M, Keshk, L. and Dorgham, L.S. (2018). "Talent Management and Its Effect on Organization Performance among Nurses at Shebin El-Kom Hospitals International Journal of Nursing, 5 (2), 108-123.

5. Azma, F, Farahbakhsh, M.T, Safarzad, R. and Farahnaki, E. (2019). Investigating Relationship of Talent Management and Organizational Entrepreneurship. International Journal of Life Sciences \& Earth Sciences, 2 (1), 25-37.

6. Abbasi, M.U, Sohail, M, Cheema, F.E.A. and Syed, N (2010). "Talent Management as Success Factor for Organizational Performance: A Case of Pharmaceutical Industry in Pakistan". IBT Journal of Business Studies (JBS), 6 (2), 74-83.

7. Smith, J. (2007). China Faces Talent Paradox, High Employee Turnover. News Alexanria, VA: Society for Human Resource Management Headline.

8. Ashton, C. and Morton, L. (2005). "Managing Talent for Competitive Advantage: Taking a Systemic Approach to Talent Management". Strategic HR Review, 4 (5), 2832.

9. Papadopoulou, G. and Vouzas, F. (2017). "Talent Management in Healthcare Organizations. International Conference for Entrepreneurship, Innovation, and Regional Development (ICEIRD 2017) Conference Book, pp. 501-512.

10. Brightman, B. (2007). "Medical Talent Management: A Model for Physician Deployment. Leadership in Health Services, 20 (1), 27-32.

11. Dünya Sağlık Örgütü (DSÖ). (2020). State of The World's Nursing Investing in Education, Jobs and Leadership.

12. Cowan, D.T, Norman, I.J. and Coopamah, V.P. (2005). "Competence in Nursing Practice: A Controversial Concept- A Focused Review of The Literature". Nurse Education Today, 25 (5), 355-362.

13. Groves, K.S. (2015). "Impact of Talent Management Practices on Hospital Clinical, Financial, \& Workforce Metrics. Healthcare Talent Management Survey, 1-68.

14. Kheirkhah, M, Akbarpouran, V. and Haghani, H. (2016). "Relationship Between Talent Management and Organizational Commitment in Midwives Working in Iran University of Medical Sciences". Journal of ClientCentered Nursing Care, 2 (3), 145-152.

15. Ohnmacht, S.D. (2016). Integrated Talent Management in Health Care: A delphi study (Doctoral dissertation, University of Phoenix). 2016.

16. Uludağ, G. (2019). "Lider Üye Etkileşiminin Yetenek Yönetimine Etkisi Üzerine Bir Alan Araştırması". Journal of the Cukurova University Institute of Social Sciences, 28 (2), 338-353

17. Kuhnert, K.W. and Lewis, P. (1987). "Transactional and Transformational Leadership: A Constructive
Developmental Analysis". Academy of Management Review, 12 (4), 648-657.

18. Alper Ay, F. ve Keleş, K. (2017). "Etkileşimci ve dönüşümcü Liderlik Tarzlarının İșten Ayrılma Niyeti ve İş Performansı Üzerinde Etkisi”. Gümüşhane Üniversitesi Sağlık Bilimleri Dergisi, 6 (4), 193-203.

19. Boamah, S.A, Laschinger, H.K.S, Wong, C. and Clarke, S. (2018). "Effect of Transformational Leadership on Job Satisfaction and Patient Safety Outcomes". Nursing Outlook, 66 (2), 180-189.

20. Roush, P.E. and Atwater, L. (1992). "Using MBTI to Understand Transformational Leadership and SelfPerception Accuracy”. Military Psychology, 4(1), 17-34.

21. Church, A.H. and Waclawski, J. (1999). "The Impact of Leadership Style on Global Management Practices". Journal of Applied Social Psychology, 29 (7), 14161443.

22. Firth-Cozens, J. and Mowbray, D. (2001). "Leadership and The Quality of Care". Quality in Health Care, 10 (suppl 2), ii3-ii7.

23. Alan, H. ve Baykal, Ü. (2018). "Yönetici Hemşirelerin Kişilik Özellikleri ve Etkileyen Kișisel ve Mesleki Özellikler”. Psikiyatri Hemşireliği Dergisi, 9 (2), 119128.

24. Basım, H.N, Cetin, F. ve Tabak, A. (2009). "Beș Faktör Kişilik Özelliklerinin Kişilerarası Çatı̧ma Çözme Yaklaşımlarıyla İlişkisi”. Türk Psikoloji Dergisi, 24 (63), 20-34.

25. Doğan, T. (2012). "Beş Faktör Kişilik Özellikleri ve Öznel İyi Oluş". Doğuș Üniversitesi Dergisi, 14 (1), 5664

26. Tutar, H, Altınöz, M. ve Çöp, S. (2011). "İșletmelerde Yetenekli Çalışanların Örgütsel Bağllılıklarının Artırılmasına Yönelik Bir Araştırma”. Çanakkale Onsekiz Mart Üniversitesi, 19. Ulusal Yönetim ve Organizasyon Kongresi, 306-312.

27. Bass, B.M. (1985).” Leadership and Performance Beyond Expectation". New York: The Free Press.

28. Avolio, B.J, Bass, B.M. and Jung, D.I. (1999). "Re-Examining The Components of Transformational and Transactional Leadership Using The Multifactor Leadership". Journal of Occupational and Organizational Psychology, 72 (4), 441-462.

29. Demir, H. ve Okan, T. (2008). "Etkileşimsel ve Dönüşümsel Liderlik: Bir Ölçek Geliştirme Denemesi”. Yönetim, 19 (61), 72-90.

30. John, O.P, Donahue, E.M. and Kentle, R.L. (1991). Big five inventory-Versions $4 \mathrm{a}$ and 54.Berkeley. University of California, Berkeley, Institute of Personality and Social Psychology, California.

31. Sümer, N, Lajunen, T. and Özkan, T. (2005). "Big Five Personality Traits as The Distal Predictors of Road Accident Involvement". In: Traffic and Transport Psychology. G. Underwood, (Ed.), Elsevier Ltd

32. Ogden, G. (2010). "Talent Management in A Time of Cost Management". Healthcare Financial Management, 64 (3), 80-84.

33. Iacono, M.V. (2008). "Showcasing Nursing Talent: Nursing Grand Rounds". Journal of Peri Anesthesia Nursing, 23 (5), 349-354.

34. Alnuqaidan, H.A. and Ahmad, M. (2019). "Comparison between Highly-Talented and Low-Talented Nurses on their Characteristics and Quality of Nursing Care". Diversity and Equality in Health and Care, 16 (2), 30-35. 
35. Weiten, W. (2010). Psychology Themes \& Variations (8th ed.). Belmont, Wadsworth: Cengage Learning.

36. Linn, G.B, Sherman, R. and Gill, P.B. (2007). Making Meaning of Educational Leadership: The Principalship in Metaphor". NASSP Bulletin, 91 (2), 161-171.

37. Laschinger, H.K.S. (2008). "Effect of Empowerment on Professional Practice Environments, Work Satisfaction, and Patient Care Quality: Further Testing The Nursing Worklife Model”. Journal of Nursing Care Quality, 23 (4), 322-330.

38. Purdy, N, Laschinger, H.K.S, Finegan, J, Kerr, M. and Olivera, F. (2010). "Effects of Work Environments on Nurse and Patient Outcomes". Journal of Nursing Management, 18 (8), 901-913. 